\title{
Knowledge of and Attitudes About Utility Pruning and How Education Can Help
}

\author{
Michael R. Kuhns and Douglas K. Reiter
}

\begin{abstract}
A survey was conducted in six cities in the western United States whose electric utilities practice directional pruning for line clearance. Recipients' knowledge of and attitudes about tree care practices and issues, utility pruning, directional pruning for line clearance, and effects of a simple brochure about utility pruning were determined. Respondents cared a great deal about landscape trees but had not thought much about utility pruning. They felt that utility pruners care most about keeping lines clear but care less about the trees, that companies are poor at explaining pruning to the public, and slightly disagree that large trees should be removed and replaced with small trees under lines. Those who had thought a lot about utility pruning were less trusting of those who do the pruning. The brochure increased trust of utility pruning personnel and the perception that they care about trees and greatly increased agreement that those personnel are highly trained professionals. Preference for topping over directional pruning was reduced by receiving a brochure, although topping still was preferred. Most supported line burial and were willing to pay higher rates for burial. Several recommendations are suggested for utilities and researchers, including the need for utilities placing an increased emphasis on communication with the public regarding these matters.
\end{abstract}

Key Words. Acceptability; aesthetics; directional pruning; electric utility; topping; urban forestry.

Directional pruning (also called natural or lateral pruning) is a valuable alternative to topping, especially for maintaining electric utility line clearance (Johnstone 1983; Shigo 1990; Kempter 2005). Many (perhaps most) electric utilities in the United States converted to directional pruning in the last 10 to 30 years (Ulrich 1987). Directional pruning consists of removing portions of a plant that are heading toward or interfering with utility lines or other objects of interest using thinning cuts and natural target pruning to facilitate compartmentalization and minimize sprouting and regrowth (Miller 1998; Kempter 2004). Plant parts not headed toward the lines or the clearance zone around the lines are left alone. It is promoted as a good alternative to topping where line clearance is achieved by rounding over or cutting back a tree's crown mostly with heading cuts, leading to poor wound closure, decay, and prolific sprouting. Directional pruning benefits trees by improving their health, benefits utilities by reducing clearance costs and possibly lengthening pruning cycles, and benefits customers by leaving them with healthier trees and minimizing landscape and neighborhood disruption (Johnstone 1988).

Ever since utilities switched to directional pruning, however, it has seemed to the authors that the public is not convinced of its value. Many complain about the look of directional pruning, especially the more extreme instances of deep V's and L's, and some (maybe many) even seem convinced that it is bad for trees. Some people prefer that the tree not be pruned at all, or if it has to be, many seem to prefer topping. Two recent examples documenting bad feelings and negative perceptions of utility pruning and its effects on trees can be found in a newspaper article about utility pruning in Salt Lake City, Utah, U.S. (Jarvik 2007) and an editorial in the Baltimore Sun (Baltimore, MD, U.S.) (Muller 2007). Flowers and Gerhold (2000) and McGillivary et al. (1996) also mention public resentment and negative feelings directed at utility companies over pruning and tree appearance. Directional pruning in the face of such resistance may lead to bad feelings and distrust of the utility or the pruning contractor and could lead to large-scale resistance at a community level. Educating people about the benefits and biology of directional pruning such as how it keeps lines clear and trees healthy may help reduce resistance to the practice and improve utility/citizen relations. Schroeder (1989) predicted some of these problems 17 years ago in a paper that reviewed the literature about people's aesthetic preferences for urban trees and discussed the implications of those preferences for utilities. He showed that people generally prefer trees with large spreading crowns rather than small trees and speculated that severe pruning of trees for line clearance could harm their aesthetics enough to create public resistance.

No studies have been published of people's attitudes and knowledge about directional pruning compared with topping 
for maintaining utility line clearance. Close et al. (2001) studied attitudes and knowledge about topping of trees with and without utilities nearby but did not deal with directional pruning. Fazio and Krumpe (1999) studied knowledge of and attitudes about topping but not directional pruning or utility pruning. Flowers and Gerhold (2000) studied attitudes about a utility tree replacement program but not about utility pruning. A search for journal articles regarding utility tree pruning in Europe and elsewhere outside the United States yielded little. A nonresearch-based report from Australia mentioned poor esthetics of pruned trees as a reason for burying utility lines (BTCE 1997). Another article (Pauleit et al. 2002) mentioned utility trenching as a limitation on urban tree success but did not mention utility pruning. Effects of education on acceptance of directional pruning and utility pruning have not been studied, but Brunson and Reiter (1996) in the United States and Jensen (2000) in Denmark found that people were more accepting of certain forest management practices if they were educated about them first.

This article reports the results of a study that examined peoples' knowledge of and attitudes about utility pruning and particularly directional pruning, and the effects of simple educational methods and messages on acceptance of directional pruning as a valid method for utility line clearing.

\section{METHODS}

A mail survey was conducted of households in six cities in the western United States. Included cities and their electric utilities were Boise, Idaho (Idaho Power, investor-owned); Salt Lake City, Utah (Rocky Mountain Power, investorowned); Phoenix, Arizona (Salt River Project, publicly owned); Albuquerque, New Mexico (New Mexico Public Service Corporation, investor-owned); Denver, Colorado (Xcel Energy, investor-owned); and Cheyenne, Wyoming (Xcel Energy, investor-owned). All six cities happen to be the largest cities and the state capitals (with the exception of Albuquerque) in their respective states, and all six are Tree City USA cities (NADF 2006b). All six utilities practice directional pruning for line clearance as a matter of policy and all have received the National Arbor Day Foundation's (NADF) Tree Line USA designation that recognizes electric utilities for their efforts to practice and promote good utility forestry, including directional pruning (Fazio 2002).

In each city, 350 randomly selected households were mailed a self-administered questionnaire consisting of an introductory letter and a nine-page survey booklet in three sections covering tree care practices and issues, including topping, utility pruning, and background information. The cover letter asked for the survey to be filled out by the adult, 18 years or older, in the household who most recently celebrated a birthday. Half of the households in each city also were sent a simple brochure entitled "Trees and Powerlines" produced by the researchers that describes why topping should no longer be done under power lines and explains directional pruning as an alternative (Kuhns 1995). The brochure describes how directional pruning is done, what it looks like, why it is better for the tree, and how it keeps lines clear longer and includes simple diagrams showing what directionally pruned versus topped trees can look like. The brochure was labeled as having come from Utah State University with no utility company endorsement indicated. If a recipient received the educational brochure, they were asked to read it before completing the questionnaire; otherwise, the questionnaires were identical.

Surveys were sent out in early 2004 using the Dillman method, including an initial mailing with a cover letter and self-addressed stamped return envelope, a reminder postcard, and a second full mailing to those who had not returned the survey (Dillman 2000). Of the 2100 questionnaires mailed, 1786 were delivered and 384 returned for a $21.5 \%$ overall response rate. We then called $10 \%$ of the nonrespondents in each city and asked a sample of the survey questions, including several of the demographic questions, to get a sense of the nonrespondent characteristics. Data compilation and statistical analysis was done using SPSS software. $\chi^{2}$ was used to determine significance of association between variables, and analysis of variance and t-tests were used to determine mean significant differences with $\alpha=0.05$.

\section{RESULTS AND DISCUSSION \\ Response Rates and Nonrespondent Characteristics}

Six cities were included in this study to extend its applicability and to avoid singling out a particular utility or city. For that reason, and because a relatively low response rate results in fairly few respondents from any one city, most data are not presented by city. Numbers of responses were highest in Boise (91) and lowest in Phoenix (46) with slightly more responses from those who did not receive the brochure than those who received it (203 versus 181).

As mentioned previously, because of our fairly low $21.5 \%$ response rate, we called $10 \%$ of nonrespondents in each city (141 total) to see how they differed from respondents. Respondents when compared with nonrespondents were older (mean age, 54 versus 50 years), were more likely to be male (57\% male versus $38 \%$ ), had higher educational attainment (56\% with college degree versus $48 \%$ ), had higher mean household income $(\$ 65,927$ versus $\$ 56,460)$, fewer were renters (14\% versus $18 \%$ ), and had less time in their present home (12 versus 15 years). Respondents also had slightly higher urban tree knowledge (2.4 versus 2.3), trees were more important to them (4.1 versus 3.8 ), were more likely to have thought about utility tree pruning (1.8 versus 1.5$)$, had attended a similar number of tree workshops, the same proportion had topped a tree, and they were less willing to pay for burying lines (2.1 versus 2.3 ) than nonrespondents (see sec- 
tions subsequently for descriptions of these questions). These differences should be taken into account when considering the applicability of these findings to the overall population of those six cities.

\section{Knowledge and Attitudes About Utility Pruning}

\section{Do People Care?}

To establish whether people care about these subjects, we asked two questions about caring - one on the importance people placed on urban trees and another on how much they had thought about utility tree pruning. Respondents placed great importance on urban trees and their health and welfare with $79 \%$ rating importance high or very high and only $4 \%$ rating it low or very low. Tree importance was not significantly affected by home ownership but was by education $(P$ $<0.010)$, income $(P<0.004)$, age $(P<0.032)$, and gender $(P$ $<0.042$ ) with trees generally rated more important as respondents' education increased, at higher income levels, for all but the oldest ages, and for females (Figure 1). Many studies have confirmed the importance and value people place on urban trees. For example, $73 \%$ of Missouri residents (Treiman and Gartner 2005), 99\% of residents of a Chicago suburb (Schroeder and Appelt 1985), and 98\% of Alabama residents (Letson 2004) agreed that trees were valuable community assets. Hunter (2001) presents a good overview of the values Europeans place on urban trees (urban forests).

Although respondents placed great importance on urban trees, most had not thought much about utility tree pruning. When they were asked "Prior to this survey, how much had you thought about utility tree pruning?," $43 \%$ replied very little or none. This might help to explain our relatively low response rate for this survey, because it might be difficult to get people to respond about something that they have not

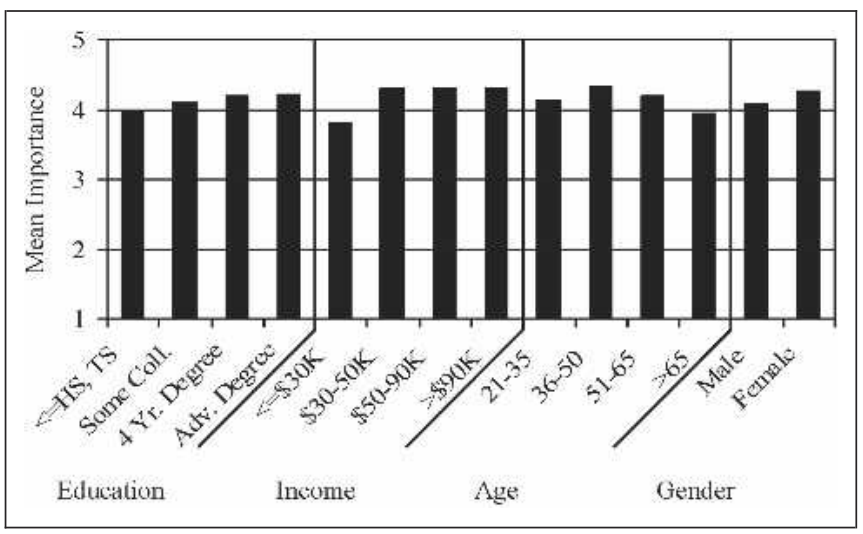

Figure 1. Mean importance ratings from the question "How would you rate the importance to you of urban trees and their health and welfare?" by education, income, age, and gender. Importance was rated as $1=$ very low, $\mathbf{2}$ = low, $\mathbf{3}=$ medium, $\mathbf{4}=$ high, and $\mathbf{5}=$ very high . Importance varied significantly for all factors at $\alpha=0.05$. thought much about and therefore might not care much about. However, another way to look at these data are that onefourth $(25.3 \%[n=93])$ of the respondents had thought quite a bit or a great deal, and over half $(56.8 \%[n=209])$ had at least thought a moderate amount about the subject. This indicates a level of thought about utility tree pruning beyond what we would have guessed. The amount of thought varied significantly by income $(P<0.046)$, those with the highest income having thought the least about utility pruning (data not shown). Thought did not vary significantly with ownership, gender, age, or education. Although some studies (e.g., Close et al. 2001) and many articles and editorials in the popular press confirm peoples' strong feelings about and dislike of utility pruning practices (e.g., Jarvik 2007 and Muller 2007), no other studies were found that determined how much people think about utility pruning or what they think about it.

\section{Knowledge of Tree Care Practices and Issues}

Most of the results on people's knowledge about topping and general tree care are not covered here. Respondents' overall self-assessment of their knowledge about urban trees and their care was fairly low with an overall mean of 2.4 in which $1=$ very low, $3=$ medium, and $5=$ very high. Knowledge varied significantly with age $(P<0.012)$, home ownership $(P<0.018)$, and gender $(P<0.018)$ with all but the youngest group, owners, and males rating their knowledge higher than the others. Knowledge did not vary significantly with income and education. Knowledge of urban trees and tree care was highly associated with thought about utility pruning $\left(\chi^{2}=\right.$ $123.888, P<0.0001)$ with those who felt they were most knowledgeable about trees more likely to have thought more about utility pruning.

\section{Knowledge of and Attitudes About Utility Pruning}

When respondents were asked to indicate who prunes trees around utilities and why, $82 \%$ correctly identified the power company as responsible, $94 \%$ correctly identified clearance for electric lines as the purpose of utility pruning $(59 \%$ said phone lines), and $75 \%$ listed public safety and $82 \%$ reducing outages as the reason pruning is done around lines. Generally it seems that respondents understand who is responsible for utility pruning and why it is done.

We assessed detailed knowledge of and attitudes about utility pruning in a respondent's area (defined as in their city) by asking their level of agreement with a series of statements about the subject with agreement indicated as $1=$ strongly disagree, 2 = disagree, $3=$ agree, and $4=$ strongly agree (Figure 2). Figure 2A-C deals with statements about harm to trees. Most responses were fairly middle of the road, assuming that an agreement value of 2.5 is the midpoint between agree and disagree. There was slight disagreement that the utility pruning done in their area harms tree health and agreement that it harms tree aesthetics. There also was agreement 


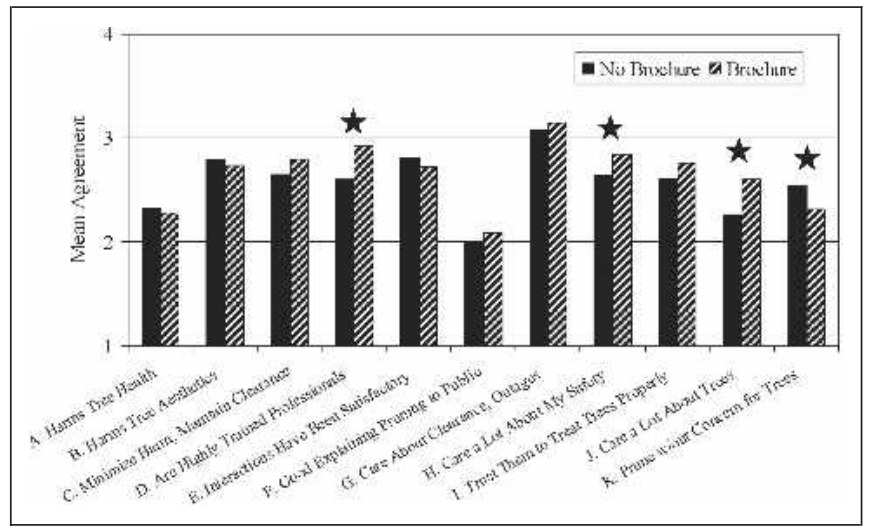

Figure 2. Mean agreement with statements about harm to trees from utility pruning and about the people who do utility pruning in their area, without and with an educational brochure, in which 1 = strongly disagree, 2 = disagree, 3 = agree, and $4=$ strongly agree. For the statements with a star, level of agreement was significantly higher if the respondent received a brochure $(P<0.001$, $0.001,0.030$, and 0.039 , respectively).

that pruning techniques are used that minimize harm to trees while maintaining clearance. Receiving a brochure had no apparent or significant effect on agreement for these three statements (based on $\chi^{2}, \alpha=0.05$ ). Figure 2D-F deals with training of utility pruning personnel and public relations. Without a brochure, agreement was only moderate that pruning officials are highly trained professionals, but this agreement was significantly strengthened for those who received the brochure $\left(\chi^{2}=10.930, P<0.012\right.$ ) (Figure 2D). The relatively few respondents $(n=82)$ who had direct interactions with pruning officials appear to have had satisfactory experiences (Figure 2E). Finally, respondents fairly strongly disagreed that utility pruning officials do a good job explaining the process to the public (Figure 2F).

Statements in Figure 2G-K deal again with utility pruning personnel, what they care about and their trustworthiness. There was strong agreement that pruning officials care a lot about line clearance and outages (Figure 2G) and weaker agreement that they care a lot about the public's safety (Figure $2 \mathrm{H}$ ) with the latter significantly increased if they received a brochure $\left(\chi^{2}=8.997, P<0.029\right)$. Three statements (Figure 2I-K) dealt with pruning personnel's care for trees. There was slight agreement that pruning officials can be trusted to treat trees properly, and this was not significantly affected by the brochure. There was disagreement that they care a lot about trees, which turned to agreement if the respondent received a brochure $\left(\chi^{2}=10.448, P<0.015\right)$. Agreement was slight for an oppositely worded statement that officials prune without concern for trees with moderate disagreement if the respondent received the brochure, although the brochure's effect was not significant at $\alpha=0.05\left(\chi^{2}=4.663, P<0.198\right)$.
Respondents' dislike of the esthetics of directional pruning, with the more severe-looking forms being disliked the most, was expected. This goes along with our personal observation that people think that directional pruning looks unnatural and possibly harmful. It also generally matches what little literature there is on the subject; Schroeder and Cannon (1983) showed that views of natural features were preferred in 16 Ohio towns, and in particular, people did not like seeing utility lines. The only other paper we found on peoples' esthetic perceptions of utility forestry practices was one titled "Esthetic perceptions of the urban forest: A utility perspective" by Schroeder (1989). Schroeder summarized research from a number of studies related to people's perceptions and preferences about urban trees and speculated on the implications of those feelings for utility arboriculture. He felt that because of peoples' preferences for large street trees with wide, spreading crowns, and because those trees are the ones most affected by utility pruning, "there are no easy solutions to the utility arborist's task." Other refereed, research-based literature on social aspects of utility forestry is almost nonexistent. We found almost no literature describing research on peoples' feelings about or trust of utility forestry personnel, although Flowers and Gerhold (2000) mention dissension and resentment directed at utility companies over pruning and unnatural tree appearance in their introduction. Also, McGillivary et al. (1996) indirectly indicated that the Kansas electric utilities they surveyed experienced problems with tree owners and poor public image.

Respondents' amount of past thought about utility pruning was significantly associated with their estimation of pruning officials' concern for their safety $\left(\chi^{2}=34.512, P<0.001\right)$ and officials' caring for trees $\left(\chi^{2}=42.965, P<0.0001\right)$; those who had thought a lot about utility pruning were less trusting (Figure 3). The proportion of respondents agreeing (agree or strongly agree) with the statements "The people who do utility pruning in my area care a lot about my safety" and "I trust the people who do utility line pruning in my area to treat the trees properly" dropped by almost half and by well over half, respectively, as the amount of thought about utility pruning went from none to a great deal. Level of past thought about utility pruning also was significantly associated with agreement about whether pruning officials show concern for trees when they prune $\left(\chi^{2}=27.479, P<0.007\right)$. Agreement with the statement "Utility pruning in my area is done without concern for how it affects the trees" almost tripled as thought went from none to a great deal (Figure 3).

This relative lack of trust that trees would be treated right from those who had thought a lot about utility pruning indicates that those thoughts tended to be negative. It is not possible to tell whether people who think a lot about utility pruning are predisposed for some reason to perceiving actions like utility tree pruning negatively or whether their thinking a lot about utility pruning is just a function of some bad pruning 


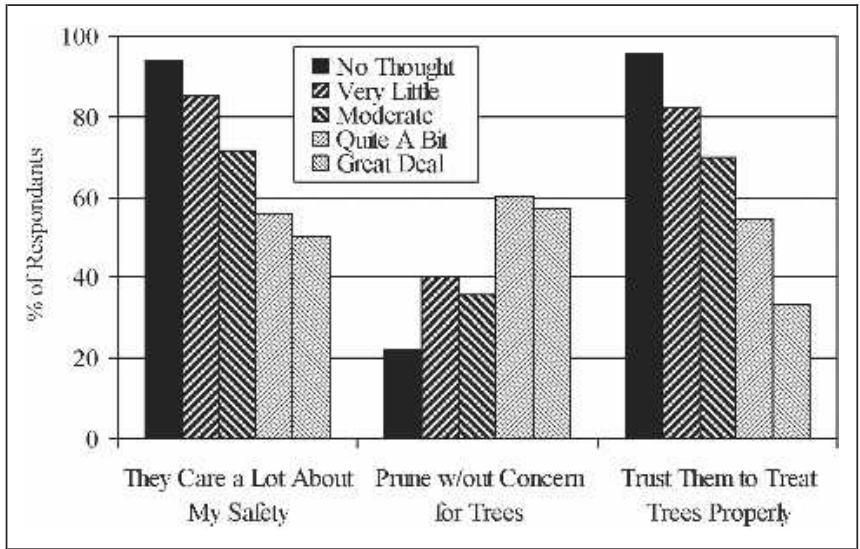

Figure 3. Proportion agreeing (agree or strongly agree) with statements about the people who do utility pruning in their area in terms of trust and care by how much they had thought about utility pruning. For each statement, agreement varies significantly with level of thought $\left(\chi^{2}\right.$; $P<0.001,0.007$, and 0.0001 , respectively).

they observed or other negative interactions. However, respondents who had thought quite a bit or a great deal about utility tree pruning were mostly the same people who rated the importance of urban trees as high or very high, so these clearly are people who care about trees. It would be easy to write off the opinions of these people, because they are a relatively small group. However, it seems likely that the people who think a lot about utility forestry may be the same people who get the attention of utility foresters, public officials, and the media when they become upset over a utility tree pruning or removal project. They also may be the most likely to want to be consulted about and involved in decisions relating to trees and utilities. Schroeder (1989) stressed the importance of such involvement as has Odom (2006) in his work in Tallahassee, Florida, and Barnes (1988) in Seattle, Washington. McGillivary et al. (1996) reported that Kansas utilities improved their customer relations and public image by involving tree owners through seeking owner permission to prune.

\section{Alternatives to Pruning: Burying Lines and Small Trees}

When there is controversy involving utility tree pruning, line burial often comes up as the public's preferred alternative to pruning or tree removal. We assessed respondents' feelings about these alternatives by asking them to indicate their level of agreement (again using a 4-point agreement scale) with statements involving line burial and small trees and by asking specifically how much they would be willing to pay to bury lines. There was fairly strong agreement that utility lines should be moved underground to avoid pruning (mean, 2.9) but disagreement that people were willing to pay significantly higher utility rates to bury the lines (mean, 2.1) with the brochure having no effect. Agreement that the lines should be moved underground and willingness to pay were highly posi- tively associated $\left(\chi^{2}=89.084, P<0.0002\right)$ with those who most strongly agreed that lines should be moved underground being the most agreeable to paying for it. Nevertheless, even those who strongly agreed that they wanted the lines moved underground only weakly agreed that they were willing to pay for their burial (mean agreement, 2.54). Respondents slightly disagreed (overall mean, 2.3) that large trees should be replaced with small trees, although agreement increased from 2.2 to 2.4 if they received the brochure $\left(\chi^{2}=6.452\right.$, $P<0.092$ ).

When respondents were specifically asked "How much more would you be willing to pay per month in increased utility rates to help pay for burying utility lines so trees will not have to be pruned for line clearance?" and were given actual rate increases to react to (no increase, $1 \%$ to $2 \%$ more, $3 \%$ to $5 \%$ more, $5 \%$ to $10 \%$ more, greater than $10 \%$ more), nearly half answered "no increase," not too surprising given the answers to the earlier question about willingness to pay (Figure 4). However, looking at it another way, more than half $(55 \%$ to $59 \%)$ were willing to pay some additional amount for line burial to avoid tree pruning, and $8 \%$ were willing to pay $5 \%$ to $10 \%$ higher rates for this purpose. The brochure had no significant effect on this willingness to pay $\left(\chi^{2}=1.291, P<0.863\right)$.

We looked further into who the people are who are willing to pay higher rates by examining how this willingness varied by respondents' level of trust that trees would be treated properly during pruning for line clearance (see Figure 2I) as well as by income and age. Willingness to pay and trust (Figure 4) were strongly negatively correlated $\left(\chi^{2}=32.677\right.$, $P<0.0001)$; respondents who expressed some level of trust

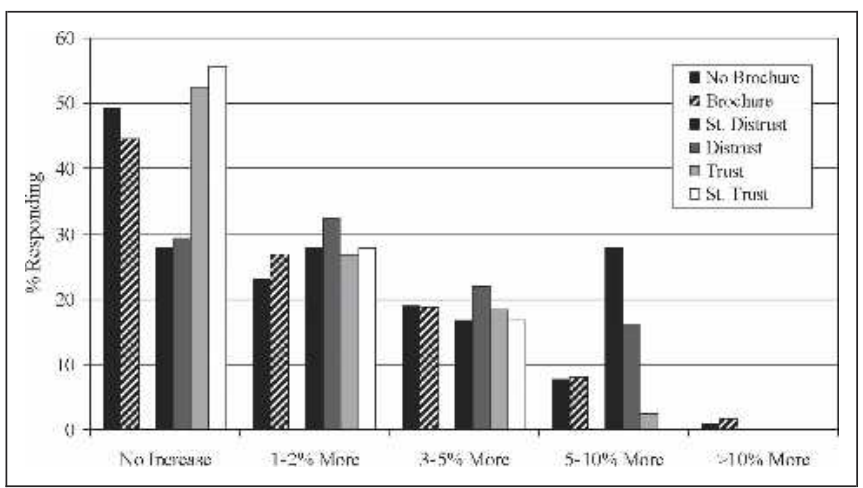

Figure 4. Proportion of respondents who were willing to pay various amounts in answer to the question "How much more would you be willing to pay per month in increased utility rates to help pay for burying utility lines so trees won't have to be pruned for line clearance?" Data are shown with and without a brochure (solid and hatched bars) and by respondents' level of trust that trees would be treated properly during pruning (solid and open bars). 
(trust or strong trust) were much less likely to want to pay anything to bury lines. Interestingly, the respondent's income was not significantly correlated with the amount they were willing to pay to bury lines (data not shown; $\chi^{2}=8.028, P$ $<0.783$ ), but age was significantly negatively correlated with willingness to pay (data not shown; $\chi^{2}=25.955, P<0.011$ ). Respondents aged older than 65 years were almost twice as likely to answer "no increase" as those aged 21 to 35 years. The strong negative correlation we observed between willingness to pay and trust seemed counterintuitive at first, but makes sense on closer examination. This result simply means that people are much less likely to want (to advocate for?) line burial if they trust that the trees will be treated well during pruning. If utilities want to avoid the push to bury lines where trees and utilities conflict, they would be well served to work to increase peoples' trust in the quality of their pruning practices.

Regardless of peoples' willingness to pay, utilities usually seem to prefer alternatives other than line burial, presumably because of technical difficulties, costs that might not entirely be passed along to rate payers, or impracticality. Even with directional pruning as an option, they usually seem to prefer removal of large-maturing trees, and if the trees are replaced, replacement with small-maturing trees. This is somewhat at odds with our results, in which respondents slightly disagreed that large tree should be replaced with small trees. Little literature is available on line burial and trees, although Goodfellow (1995) described various engineering alternatives to line-clearance pruning, including burial. He points out that buried electrical utilities in urban areas are generally more expensive to build and that often "there is little or no financial incentive for a utility to pursue conversion" to underground lines. However, he also feels that "underground construction is often the only acceptable method for new construction in urban and residential areas" (Goodfellow 1995), and he points out some trends that make it seem likely that line burial would become more common in the future (his article is now 11 years old). An Australian government report (BTCE 1997) lists improved tree esthetics through avoidance of utility pruning as a benefit of line burial.

\section{Tree Appearance}

Our impression in dealing with utility customers and foresters over the years is that the primary reason people react negatively to directional pruning for line clearance is aesthetics. Certainly this goes along with the findings presented earlier, in which respondents agreed that utility pruning in their area harms tree aesthetics. To explore this further, we asked respondents to react to four drawings of trees pruned for utility clearance: (A) a topped tree with lines overhead, (B) a tree pruned to a $\mathrm{V}$ with lines overhead, $(\mathrm{C})$ a tree pruned to an $\mathrm{L}$ with lines to the side, and (D) a one-sided tree with lines to the side (Figure 5). We explained that trees take on a certain appearance depending on how they are pruned for utility clearance and that the diagrams showed how they might look shortly after pruning. A weakness of this method is that the drawings were arguably idealized representations of topped and directionally pruned trees; nevertheless, the results are interesting. Also, note that earlier in the questionnaire, topping was defined as "the practice of rounding over or cutting back a tree's crown, usually to keep it smaller than it would normally grow" and three photographs were included of some fairly severely topped trees. Respondents were asked whether they preferred the look of A or B when lines are overhead, the look of $\mathrm{C}$ or $\mathrm{D}$ when lines are to the side, and whether $\mathrm{A}$ or $\mathrm{B}$ is better for the tree and better for line clearance. They also were asked to choose the one that looks worst-A, B, C, or $\mathrm{D}$ - and the ones most like the utility pruning done in their area (Figure 6).

Respondents greatly preferred the appearance of the topped tree to the V'ed tree (Figure 5). However, the topped tree admittedly had a fairly nicely "hedged" look to it rather than the gnarly look that topped trees often have. Acceptance of the $\mathrm{V}$ and $\mathrm{L}$ was next, and fairly equal, and the one-sided tree looked the worst by far (Figure 6). When forced to choose the looks of the L'ed tree versus the one-sided, respondents preferred the $\mathrm{L}$ with its greater amount of retained crown (Figure 5). Receiving a brochure made the look of the $\mathrm{V}$ more acceptable $\left(\chi^{2}=37.526, P<0.0001\right)$ in comparison to the topped tree, but the topped look was still preferred almost two

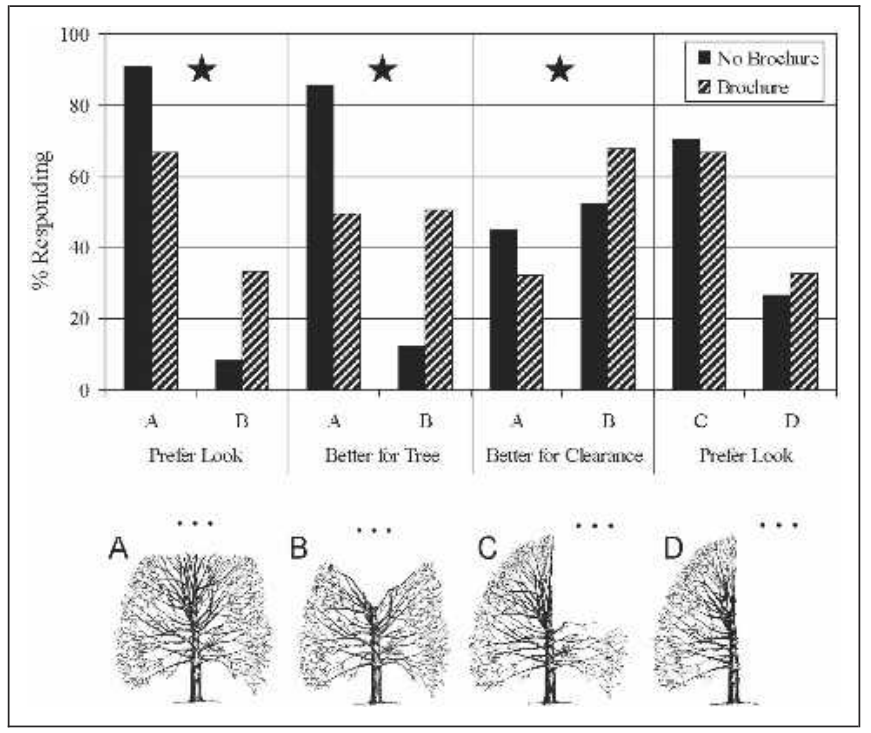

Figure 5. Proportion of respondents who prefer the look of A or $B$, think $A$ or $B$ is better for the tree, think $A$ or $B$ is better for line clearance, and prefer the look of $C$ or $D$. Data are shown with and without a brochure. Stars indicate significant association between respondents' choices and receiving a brochure $\left(\chi^{2} ; P<0.0001,0.0001\right.$, and 0.009 , respectively). 


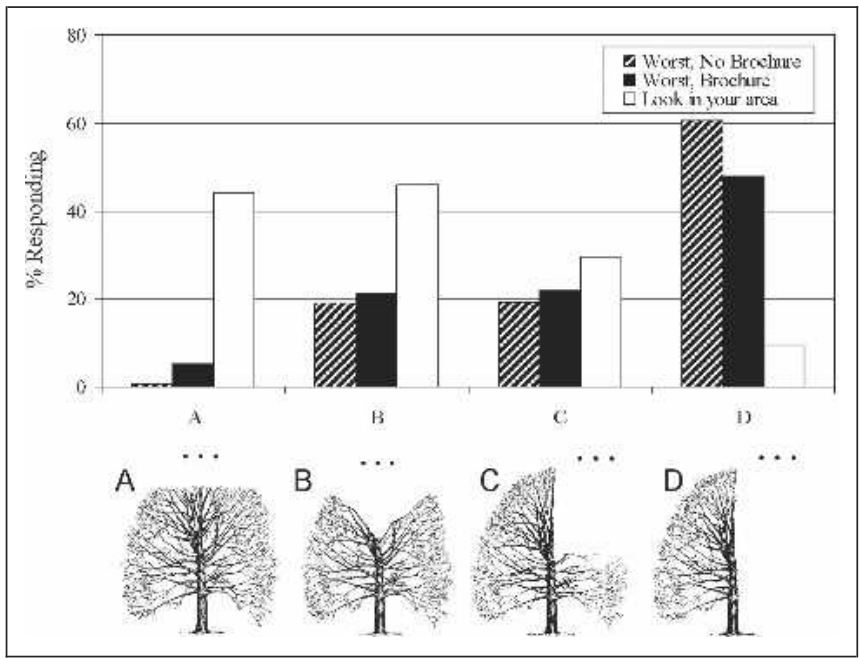

Figure 6. Proportion of respondents who think A, B, C, or D looks the worst without and with the brochure (choosing only one; hatched and solid black bars) and who think A, $B, C$, or D look like the utility-pruned trees in their area (they could choose more than one; white bars).

to one over the V. The brochure had no effect on preference for the look of the L versus the one-sided tree; either way people preferred the $\mathrm{L}$. Receiving a brochure did significantly decrease disapproval of the one-sided tree $\left(\chi^{2}=15.215, P<\right.$ 0.019) (Figure 6).

Without the brochure, respondents were seven times more likely to feel that the pruning done for the topped tree was better for the tree than that done for the V'ed tree (Figure 5). With the brochure, however, which focused heavily on these issues, those proportions changed with slightly more thinking the $\mathrm{V}$ pruning was better than the topping. This significant effect of a simple educational brochure $\left(\chi^{2}=63.235, P<\right.$ 0.0001 ) is encouraging, although we had hoped the brochure would have had an even greater effect. Respondents felt that the V'ed tree was better for line clearance with the brochure increasing this feeling almost two to one over the topped tree $\left(\chi^{2}=11.467, P<0.009\right)$. Presumably this is because the nearest branches to the lines were farther away on the V'ed tree than the topped tree.

Schroeder and Cannon (1983), as mentioned previously, found that people preferred streetscapes with trees with a fairly natural appearance and utility lines not showing, and Schroeder (1989) mentioned that people preferred broadspreading tree canopies. This could help explain peoples' dislike of the V, L, and one-sided trees we presented but does not explain their preference for the topped look. It could be that the idealized topped tree appearance may have looked the least harsh or unnatural. Fazio and Krumpe (1999) found that very few people who topped trees or had them topped did it because they like the look of it. Close et al. (2001) reported that $16 \%$ of people in several Illinois towns who had their trees topped did it solely for aesthetic reasons. It is important to note in the current study that showing preference for the appearance of a practice does not necessarily equate to endorsement of that practice; it may just be the least objectionable of the choices they were presented.

All of the respondents were living in cities served by electric utilities that had received the Tree Line USA award from the NADF for multiple years. Presumably topping of trees under the electric lines happens little, if at all, because program requirements implicitly forbid topping. In fact, the Vlook was chosen by the greatest proportion of respondents as the look of utility pruning in their area (Figure 6). However, close behind the $\mathrm{V}$ was the topped tree; over $40 \%$ of respondents felt that the topped tree looks like the utility pruning they are seeing in their area. Perhaps this relates to the twodimensional representations used in the survey versus the three-dimensional trees people would actually see. Often portions of a tree's crown or other trees' crowns obscure the $\mathrm{V}$ shape depending on one's point of view. It also could be that some people have viewed properly pruned excurrent-form trees that are not easily pruned into Vs and may appear to have been topped. Substantially fewer thought they were seeing Ls, and very few were seeing one-sided trees, reflecting our observation that such trees are relatively rare.

\section{Tree Line USA and Tree City USA}

All utilities included in this study were recipients of the Tree Line USA award that recognizes utilities for treating trees right (NADF 2006a). Because this program seemed to have great potential to increase trust and perceived professionalism of utility foresters and arborists, we asked respondents about their familiarity with the program. We also asked whether they were familiar with the Tree City USA program, because all six cities are long-time Tree City USA awardees. Tree City USA is a NADF program that recognizes cities for having active, quality urban/community forestry programs (NADF 2006b).

It appears that utilities and cities may not be fully using the potential of the Tree Line USA and Tree City USA programs for generating public support. Most respondents (90\% overall) had definitely never heard of the Tree Line USA program, and only four individuals had definitely heard of it and knew what it was (Figure 7). Recognition, indicated by the percentage who had at least possibly heard of the program, varied from $4 \%$ to $15 \%$ and was highest in Salt Lake City with Rocky Mountain Power and lowest in Albuquerque with New Mexico Public Service. Results were better for Tree City USA, but still $74 \%$ had definitely never heard of the program (Figure 7). Tree City USA recognition varied widely, with Cheyenne having $48.5 \%$ recognition and 22 years in the program, Boise $18.1 \%$ and 26 years, and Albuquerque $12.5 \%$ and 7 years. 


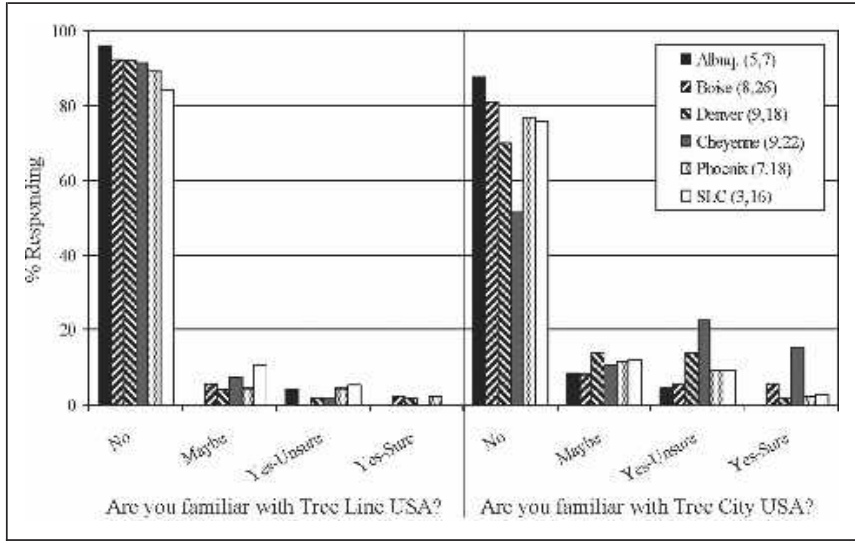

Figure 7. Respondents' familiarity with the Tree Line USA and Tree City USA programs by utility/city. Actual answer choices were: no-definitely never heard of it; maybemight have heard of it; yes-unsure-heard of it, but not sure what it is; yes-sure-definitely heard of it; and I know what it is. Numbers in legend are the number of years in each program.

Tree Line USA is promoted in a number of ways. A web search showed that the NADF posts news releases acknowledging recipients. A search with the company name followed by Tree Line USA, and a search of the corporate web sites, revealed the following program promotions, ordered from highest to lowest recognition:

Rocky Mountain Power; Salt Lake City, Utah, U.S.; 15\% recognition; awarded for 3 years; article in customer newsletter; mention in press release and environmental report.

Salt River Project; Phoenix, Arizona, U.S.; 10.8\% recognition; 7 years; mention on web page.

Xcel Energy; Denver, Colorado, and Cheyenne, Wyoming, U.S.; $8 \%$ to $9 \%$ recognition; 9 years; mention on trees and power lines web page and in 2001 midwestern-area trimming program news release.

Idaho Power; Boise, Idaho, U.S.; 7.7\% recognition; 8 years; mention on a tree safety and reliability web page and in a 2001 news release.

New Mexico Public Service; Albuquerque, New Mexico, U.S.; 4\% recognition; 5 years; mention in several news releases and a tree care booklet.

Rocky Mountain Power's Tree Line USA public relations efforts may have been more effective than the other utilities given their relatively high recognition compared with the others and despite the fact that they had received the award for the shortest amount of time, 3 years.

No published research was found on the Tree Line USA program. Several studies mentioned Tree City USA, possibly because it has been around much longer. A recent study in Missouri (Treiman and Gartner 2005) found that 60\% to $96 \%$ of residents did not know or were wrong about whether their community was a Tree City USA. Grado et al. (2006) found that $49 \%$ of Mississippi community officials were aware of Tree City USA, although communities with under 10,000 population were less aware. Other recent studies mentioning the Tree City USA program, although not focusing on program recognition, include studies of community officials in Missouri (Treiman and Gartner 2004) and Maryland (Galvin and Bleil 2004).

\section{Educational Sources and Trust}

Respondents were asked to indicate which information source (selecting only one from a list) "that you would trust the most to help you learn about utility line pruning." The most trusted source was Extension, selected by over twice as many people as the next highest sources, arborists and state forestry (Figure 8). Tree nonprofits, the web, family, and friends were least chosen. Although utilities would presumably be thought of as knowing a lot about utility pruning, they were only fourth highest in terms of trust with $10.5 \%$ selecting them as the most trusted source for such information. Extension's high level of trust probably relates to its presence in nearly every county, its noncommercial, impartial nature, and its connection with respected land grant universities in each state. The high value placed on Extension as a tree/forest information source has been confirmed in other studies (Kuhns et al. 2005, 1998), although never before in relation to utility pruning. State forestry agencies also were highly trusted, possibly again related to their noncommercial and impartial nature. Arborists' relatively high trust is heartening but more difficult to explain because they are commercial. Evidently they must be considered impartial when it comes to utility pruning.

\section{Recommendations}

Our recommendations based on our findings and the literature are that, above all, utilities and those they cooperate with need to emphasize communication with the public. As stated

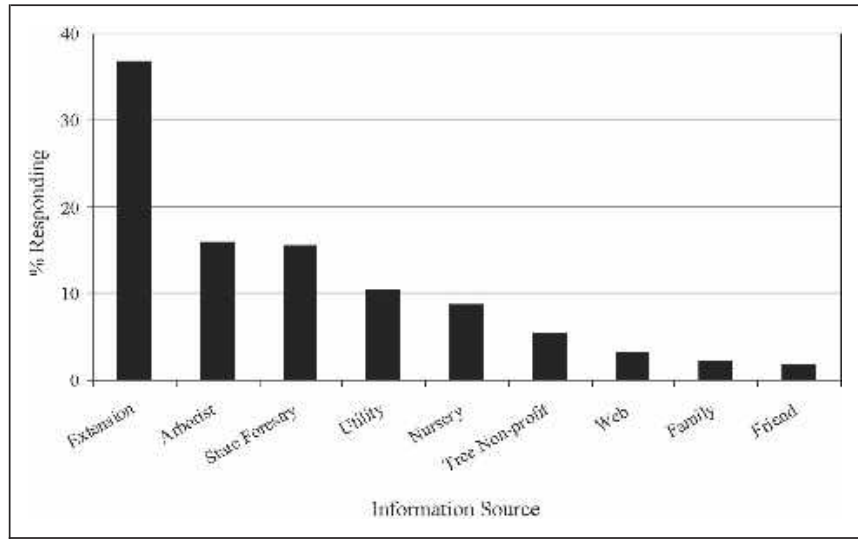

Figure 8. Proportion of respondents selecting a source as the most trusted for learning more about utility pruning. 
by Schroeder (1989), "it is important to involve local residents in decisions affecting their trees and utilities." Outreach and education about pruning techniques and the importance of maintaining clearance is very important. Negative effects of topping also need to be made clear, because those who think that topping is alright for the tree will likely prefer it over directional pruning. Brochures can be effective but may need to focus more intensively than ours on the evils of topping as well as explaining that the soft hedged look of some topped trees belies hidden weaknesses and future problems. Utilities also could and should make much more use of the positive aspects of their Tree Line USA designation. This could go a long way toward increasing trust of the utility and its motives in line clearance, trust that could buy public goodwill in high-profile removal or pruning situations or could keep some situations from becoming high profile. Also, more research is warranted on the Tree Line USA and Tree City USA programs and how to make the most of their potential to bolster public support and knowledge.

Utilities also would be well served to maintain greater trust by looking for and recognizing situations likely to result in high conflict and avoiding them when possible. Although large tree removal often is the utility's preferred mode, sometimes going to the public or a city with removal as your first preference and intention will damage credibility when directional pruning is an option. For example, removal of a silver maple (Acer saccharinum), cottonwood (Populus spp.), or eucalyptus (Eucalyptus spp.) under power lines in an alley makes a lot of sense and may be unlikely to raise widespread public concern. Removal of the same species under a power line along a city street also makes a lot of sense, because these species are unlikely to be valuable contributors to the urban forest in such a situation. On the other hand, trying to remove a row of oaks (Quercus spp.) under power lines down a main street through a historic neighborhood may make sense from an economic perspective but is much more likely to cause public outcry and may damage the credibility of the utility trying to do the removal. This might be a case in which advocating for directional pruning and accepting that "the right tree in the right place" does not always have to be a small tree may be the best way for the utility to maintain its credibility. It also is in keeping with the spirit of the Tree Line USA recognition program, which requires that "directional pruning is used when possible to prevent removal of large trees" (Fazio 2002).

Acknowledgments. Support for this project came from the ISA Duling Grants (now the TREE Fund), the Institute for Outdoor Recreation and Tourism at Utah State University, and the Utah Agricultural Experiment Station, Logan, Utah (ap-

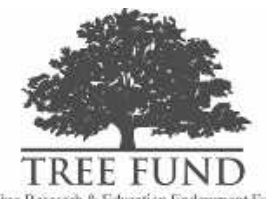
proved as journal paper no. 7847). We thank Ms. Susan Durham for help with statistical analysis.

\section{LITERATURE CITED}

Barnes, B. 1988. Community involvement/public outreach in line clearance. Journal of Arboriculture 14:298-301.

Brunson, M.W., and D.K. Reiter. 1996. Effects of ecological information on judgments about scenic impacts of timber harvest. Journal of Environmental Management 46: 31-41.

Bureau of Transport and Communications Economics (BTCE). 1997. Measuring the Benefits of Putting Cables Underground. Report published by BTCE, Canberra, Australia. www.dcita.gov.au/cables/files/bureau_a.doc (accessed 01/24/07).

Close, D.D., J.W. Groninger, J.C. Mangun, and P.L. Roth. 2001. Homeowners' opinions on the practice and effects of topping trees. Journal of Arboriculture 27:160-165.

Dillman, D.A. 2000. Mail and Internet surveys: The tailored design method. John Wiley and Sons, New York.

Fazio, J.R. 2002. Tree Line USA. Tree City USA Bulletin No. 25, J.R. Fazio, ed. National Arbor Day Foundation, Nebraska City, NE.

Fazio, J.R., and E.E. Krumpe. 1999. Underlying beliefs and attitudes about topping trees. Journal of Arboriculture 25: 192-199.

Flowers, D.E., and H.D. Gerhold. 2000. Replacement of trees under utility wires impacts attitudes and community tree programs. Journal of Arboriculture 26:309-318.

Galvin, M.F., and D. Bleil. 2004. Relationship among tree canopy quantity, community demographics, and Tree City USA program participation in Maryland, U.S. Journal of Arboriculture 30:321-327.

Goodfellow, J.W. 1995. Engineering and construction alternatives to line clearance tree work. Journal of Arboriculture 21:41-49.

Grado, S.C., D.L. Grebner, M.K. Measells, and A.L. Husak. 2006. Status, needs, and knowledge of Mississippi's communities relative to urban forestry. Journal of Arboriculture 32:24-32.

Hunter, I.R. 2001. What do people want from urban forestry?-The European experience. Urban Ecosystems 5: 277-284.

Jarvik, E. 2007. Pruning is tricky mix of aesthetics, safety. Deseret Morning News, 8 January 2007. www.deseretnews. com (accessed 01/24/07).

Jensen, E.V. 2000. The effects of information on Danish forest visitors' acceptance of various management actions. Forestry 73:165-172.

Johnstone, R.A. 1983. Management techniques for utility tree maintenance. Journal of Arboriculture 9:17-20.

1988. Economics of utility lateral trimming. Journal of Arboriculture 14:74-77. 
Kempter, G. 2004. Best management practices: Utility pruning of trees. International Society of Arboriculture, Champaign, IL.

. 2005. Utility pruning. Arborist News 14:12-17.

Kuhns, M.R. 1995. Trees and power lines. Leaflet 270, USU Extension.

Kuhns, M.R., M.W. Brunson, and S.D. Roberts. 1998. Landowners' educational needs and how foresters can respond. Journal of Forestry 96:38-43.

Kuhns, M.R., B. Lee, and D.K. Reiter. 2005. Characteristics of urban forestry programs in Utah, U.S. Journal of Arboriculture 31:285-295.

Letson, N. 2004. Survey says-Alabama citizens like urban trees. Action (from Alabama Cooperative Extension), Fall 2004, pp. 1-2.

McGillivary, L., S. Wiest, and D. Hensley. 1996. A survey of utility line clearance operations in Kansas. Journal of Arboriculture 22:281-282.

Miller, R. 1998. Why utilities V-out trees. Arborist News 7:9-14.

Muller, R.J. 2007. City's trees get no respect. Baltimore Sun, 10 January 2007. www.baltimoresun.com (accessed 01/ 24/07).

National Arbor Day Foundation (NADF). 2006a. Tree Line USA web page. Www.arborday.org/programs/ treeLineUSA.cfm (accessed 08/21/06).

— 2006b. Tree City USA web page. www.arborday. org/programs/treeCityUSA.cfm (accessed 08/18/06).

Odom, F.P. 2006. Less is more: Utility line clearance in Tallahassee, Florida. In: Energy pulse. www.energypulse. net (accessed 09/26/06).

Pauleit, S., N. Jones, G. Garcia-Martin, J.L. GarciaValdecantos, L.M. Rivière, L. Vidal-Beaudet, M. Bodson, and T.B. Randrup. 2002. Tree establishment practice in towns and cities-Results from a European survey. Urban Forestry and Urban Greening 1:83-96.

Schroeder, H.W. 1989. Esthetic perceptions of the urban forest: A utility perspective. Journal of Arboriculture 15:292-294.

Schroeder, H.W., and P. Appelt. 1985. Public attitudes toward a municipal forestry program. Journal of Arboriculture 11:18-21.

Schroeder, H.W., and W.N. Cannon. 1983. The esthetic contribution of trees to residential streets in Ohio towns. Journal of Arboriculture 9:237-243.

Shigo, A.L. 1990. Pruning trees near electric utility lines. Shigo and Trees Associates, Durham, NH.

Treiman, T., and J. Gartner. 2004. Community forestry in Missouri, U.S.: Attitudes and knowledge of local officials. Journal of Arboriculture 30:205-213.

- 2005. What do people want from their community forests? Results of a public attitude survey in Missouri, U.S. Journal of Arboriculture 31:243-250.

Ulrich, E.S. 1987. Utility line clearance in our urban forests. Journal of Arboriculture 13:62-64.
Michael R. Kuhns (corresponding author)

Professor

Department of Wildland Resources

Utah State University

Logan, UT 84322-5230, U.S.

mike.kuhns@usu.edu

Douglas K. Reiter
Research Associate
Institute for Outdoor Recreation and Tourism
Utah State University
Logan, UT 84322-5215, U.S.

Résumé. Une enquête a été menée auprès de six villes de l'Ouest des États-Unis où l'élagage directionnel est utilisé pour effectuer le dégagement des lignes électriques. Les connaissances et les réactions des bénéficiaires à propos des enjeux et des techniques d'entretien, le dégagement des lignes, l'élagage directionnel et les effets d'une simple brochure à propos du dégagement directionnel des lignes ont été étudiés. Les répondants tenaient beaucoup à l'entretien de leurs arbres ornementaux mais n'avaient pas vraiment réfléchi sur la question du dégagement des lignes électriques. Ils estimaient que les élagueurs étaient plus sensibles à tenir les lignes dégagées et moins à la santé des arbres, que les compagnies étaient mauvaises pour expliquer l'élagage au public, et ils étaient légèrement en désaccord avec l'abattage des grands arbres et leur remplacement par des petits arbres sous les réseaux électriques. Ceux qui avaient réfléchi longuement à propos du dégagement des lignes faisaient encore moins confiance à ceux qui effectuaient ces travaux. La brochure permettait d'accroître la confiance envers le personnel affecté à cette tâche et la perception que ces derniers étaient sensibles au bien des arbres, et aussi d'accroître grandement l'opinion que ce personnel était des professionnels hautement entrânés. La préférence envers l'écimage plutôt que l'élagage directionnel était diminuée suite à la réception de cette brochure, et ce bien que l'écimage avait encore la préférence majoritaire. La plupart des gens supportait l'enfouissement des réseaux et était enclin à payer des taux plus élevés en ce sens. Plusieurs recommandations sont suggérées pour les compagnies de services publics et les chercheurs, et ce incluant la localisation des lignes et une emphase accrue sur la communication avec le public en regard de ces sujets.

Zusammenfassung. In sechs Städten der westlichen Vereinigten Staaten, die denen die Stromversorger die Praxis des radikalen Rückschnitts unterhalb der Leitungen verfolgen, wurde eine Umfrage durchgeführt. Hier wurde das Wissen um und die Einstellungen zu Baumpflege und verwandten Themen, Rückschnitt unter Leitungen, zielgerichteter Rückschnitt und der Einfluss einer einfachen Broschüre zum Thema Rückschnitt erfasst. Die Teilnehmer sorgten sich sehr um die Bäume, aber machten sich wenig Gedanken zu Baumschnitt unter Leitungen. Sie glaubten, dass die beauftragten Firmen hauptsächlich an der Sauberkeit der Leitung interessiert waren, sich aber weniger um Bäume sorgten, dass die Firmen wenig in der Lage waren, ihre Arbeit für eine Öffentlichkeit zu beschreiben und stimmten nicht immer zu, dass große Bäume von der Leitung entfernt und durch kleinere ersetzt würden. Diejenigen, die sich sehr 
für den Rückschnitt engagierten, vertrauten den durchführenden Firmen weniger. Die Broschüre verstärkte das Vertrauen in die beauftragten Firmen und die Wahrnehmung, dass sie sich wirklich um Bäume kümmern und verstärkte besonders die Anerkennung, dass es sich hier um geschultes Fachpersonal handelte. Die Bevorzugung von Kronenkappen gegenüber selektivem Rückschnitt wurde durch den Erhalt der Broschüre vermindert, aber Kronenkappen wurde nach wie vor bevorzugt. Viele unterstützten das Begraben der Linie und waren bereit, dafür höhere Beiträge zu zahlen. Einige Empfehlungen für die Leitungen und Forscher wurden gegeben, einschließlich dem Bedürfnis, dass die Firmen mehr Aufmerksamkeit auf die Kommunikation mit der Öffentlichkeit legen sollten.

Resumen. Se condujo una encuesta en seis ciudades en el oeste de los Estados Unidos, que practican poda direccional en líneas eléctricas. Se determinó el conocimiento de los receptores acerca de sus actitudes sobre las prácticas de cuidados de los árboles, poda en líneas de servicios, poda direccional para liberación de líneas y sus impresiones acerca de un folleto sobre la poda. Los respondientes privilegiaron un buen cuidado de los árboles en el paisaje, pero no consideraron mucho la poda utilitaria. Ellos sienten que los podadores utilitarios piensan más en mantener limpias las líneas aéreas que en cuidar a los árboles; que las compañías son deficientes en explicar la poda al público, y están un poco en desacuerdo en que los grandes árboles deban ser removidos y remplazados por árboles pequeños bajo las líneas aéreas. El folleto incrementó la confianza en la poda utilitaria y la percepción de que las empresas cuidan los árboles; también aumentó la confianza de que es profesional altamente calificado. El folleto redujo las preferencias por el desmoche sobre la poda direccional, aunque el desmoche sigue siendo aceptado. La mayoría apoyó las líneas subterráneas y estuvieron dispuestos a pagar altas tasas por la excavación. Se sugieren varias recomendaciones para los prestadores de servicios e investigadores, incluyendo la necesidad de reubicar las líneas y un énfasis en la comunicación, con el acuerdo del público en estas materias. 